\title{
The era of precision oncogenomics
}

\author{
John C. Carpten ${ }^{1}$ and Elaine R. Mardis ${ }^{2}$ \\ ${ }^{1}$ Department of Translational Genomics and Institute for Translational Genomics, Keck School of Medicine of \\ the University of Southern California, Los Angeles, California 90089, USA; ${ }^{2}$ Institute for Genomic Medicine at \\ Nationwide Children's Hospital and Department of Pediatrics, The Ohio State University, Columbus, Ohio \\ 43215, USA
}

Cancer is a disease of the genome, the complexities of which have been unraveled over time and with improvements in technology. Microscopy-based studies of cancer chromosomes in the 1970s revealed relationships between specific chromosomal DNA aberrations and cancers. These observations were refined by molecular biology-based cloning, Southern blotting, and DNA sequencing in the 1980s that identified translocated and amplified oncogenes, including BCR-ABL in chronic myeloid leukemia and ERBB2 (HER2) in breast cancers. Oncogenic proteins consequently became the focus of therapeutic development aimed at shutting down their aberrant functions and halting tumor progression. An example of this paradigm is the breast cancer subtype known as "HER2 positive," in which a segment of Chromosome 17 harboring the HER2 gene is amplified, producing extra copies. The resulting overabundance of HER2 protein, a tyrosine kinase, leads to the development of an aggressive subtype of breast cancer (Slamon et al. 1987). Several HER2-targeted therapies now are FDA-approved because of their ability to prolong survival in patients whose cancers have this driver alteration (Slamon et al. 2001).

With the completion of the Human Genome Project in 2003, cancer researchers could identify tumor-specific somatic alterations in cancers. This provided the opportunity to explore gene-drug interactions in the context of specific targeted therapies such as tyrosine kinase inhibitors. In the latter approach, gene-specific PCR and Sanger sequencing were used to characterize the mutational status of genes in cancer patients who either did or did not respond to treatment with these new small-molecule inhibitors (Lynch et al. 2004; Paez et al. 2004; Pao et al. 2004). These and other studies provided evidence of links between genes, specific alterations, and therapeutics and ushered in novel diagnostic paradigms that involved DNA sequencing. Genomic discovery efforts in cancer were signifi-

Corresponding author: elaine. mardis@nationwidechildrens.org

C) 2018 Carpten and Mardis This article is distributed under the terms of the Creative Commons Attribution-NonCommercial

License, which permits reuse and redistribution, except for commercial purposes, provided that the original author and source are credited.

Published by Cold Spring Harbor Laboratory Press

doi: $10.1101 /$ mcs.a002915 cantly accelerated with the advent of next-generation sequencing methods and their application to the study of cancer genomes, starting in 2008 (Ley et al. 2008). These studies have permitted genomic alterations from tens of thousands of cancers to be characterized at single-nucleotide resolution and have enhanced our appreciation of how each cancer genome is created from different combinations of somatic alterations. As a consequence of sequencing matched normal genomes from cancer patients, we better understand the scope of inherited and de novo germline alterations that result in cancer susceptibility.

Indeed, this new understanding of cancer as a disease of the genome coupled with our ability to comprehensively interrogate tumors allows us to intelligently exploit cancer genomic vulnerabilities using target-specific therapies. Consequently, a "precision" approach to cancer treatment has emerged, based on the use of next-generation sequencing, advanced analytics, and databases meant to predict therapeutic targets for individual patients. This special print issue of Cold Spring Harbor Molecular Case Studies explores and celebrates this current paradigm by featuring a full range of manuscripts and commentaries that 
Competing Interest Statement The authors have declared no competing interest. exemplify how cancer precision medicine is being applied, and how our understanding of the genomic features of cancers continues to grow. These contributions outline the complex data types, analytical approaches, and cancer-specific databases required to precisely characterize individual cancer genomes and identify likely drug targets from the cancer pharmacopeia. They describe genomic discoveries in rare cancer types, precision cancer medicine studies of individual patients, therapy resistance mechanisms, and other important aspects of this emerging discipline. Commentaries explore the personal side of what it is like to benefit from a genomic diagnosis, to create tools that aid in interpreting cancer genomic data, to organize efforts that expand access to these modern approaches and educate providers via molecular tumor boards, and to elicit changes in current medical practice as a result of one's efforts.

The contents of this special issue provide a glimpse into current cancer precision medicine efforts, reflecting only a microcosm of the current applications of genomics in this bustling space of clinical translation. Although exciting and new, we also understand that we have only scratched the surface of our ability to characterize cancer at a molecular level, and there are important research-based efforts that will result in continuing changes to this emergent discipline. We are also focused on specific challenges in cancer precision medicine that include access to advanced genomics-based characterization. Hopefully, genomics-based diagnostics and the indicated targeted therapies can be offered to all cancer patients who might benefit, regardless of socioeconomics or race/ethnicity. Moreover, as we increase the diversity of patients participating in cancer genomics studies, we will likely uncover new context to further personalize these precision approaches to cancer treatment and management.

We would like to thank the many groups and individuals who contributed to the special print issue, and we hope these contributions will be of interest and inspiration to our readers. We especially acknowledge and thank the patients and families whose personal journeys with cancer have formed the content of this issue. We welcome those attending the AACR Annual Meeting in Chicago this April (14th-18th) to stop by the Cold Spring Harbor Press booth and collect a copy of the issue.

\section{REFERENCES}

Ley TJ, Mardis ER, Ding L, Fulton B, McLellan MD, Chen K, Dooling D, Dunford-Shore BH, McGrath S, Hickenbotham $M$, et al. 2008. DNA sequencing of a cytogenetically normal acute myeloid leukaemia genome. Nature 456: 66-72.

Lynch TJ, Bell DW, Sordella R, Gurubhagavatula S, Okimoto RA, Brannigan BW, Harris PL, Haserlat SM, Supko JG, Haluska FG, et al. 2004. Activating mutations in the epidermal growth factor receptor underlying responsiveness of non-small-cell lung cancer to gefitinib. N Engl J Med 350: 2129-2139.

Paez JG, Jänne PA, Lee JC, Tracy S, Greulich H, Gabriel S, Herman P, Kaye FJ, Lindeman N, Boggon TJ, et al. 2004. EGFR mutations in lung cancer: correlation with clinical response to gefitinib therapy. Science 304: $1497-1500$

Pao W, Miller V, Zakowski M, Doherty J, Politi K, Sarkaria I, Singh B, Heelan R, Rusch V, Fulton L, et al. 2004. EGF receptor gene mutations are common in lung cancers from "never smokers" and are associated with sensitivity of tumors to gefitinib and erlotinib. Proc Natl Acad Sci 101: 13306-13311.

Slamon DJ, Clark GM, Wong SG, Levin WJ, Ullrich A, McGuire WL. 1987. Human breast cancer: correlation of relapse and survival with amplification of the HER-2/neu oncogene. Science 235: 177-182.

Slamon DJ, Leyland-Jones B, Shak S, Fuchs H, Paton V, Bajamonde A, Fleming T, Eiermann W, Wolter J, Pegram $M$, et al. 2001. Use of chemotherapy plus a monoclonal antibody against HER2 for metastatic breast cancer that overexpresses HER2. N Engl J Med 344: 783-792. 


\section{$\$_{\text {CSH }}^{\infty}$ C O L D S P R I n G H A R B O R
$\$_{\infty} \&_{\text {Molecular Case Studies }}$}

\section{The era of precision oncogenomics}

John C. Carpten and Elaine R. Mardis

Cold Spring Harb Mol Case Stud 2018, 4: a002915

Access the most recent version at doi:10.1101/mcs.a002915

References This article cites 6 articles, 3 of which can be accessed free at:

http://molecularcasestudies.cshlp.org/content/4/2/a002915.full.html\#ref-list-1

License This article is distributed under the terms of the Creative Commons Attribution-NonCommercial License, which permits reuse and redistribution, except for commercial purposes, provided that the original author and source are credited.

Email Alerting Receive free email alerts when new articles cite this article - sign up in the box at the Service top right corner of the article or click here. 